\title{
Accounting Earnings Response Coefficient: Is the Earning Response Coefficient Better or Not
}

\author{
Ratna Wijayanti Daniar PARAMITA ${ }^{1}$, Isti FADAH ${ }^{2}$, Diana Sulianti K. TOBING ${ }^{3}$, Imam SUROSO ${ }^{4}$
}

Received: June 22, 2020 Revised: August 23, 2020 Accepted: August 30, 2020

\begin{abstract}
The study aims to compare whether using Earnings Response Coefficient (ERC) is better than using the new concept of Accounting Earnings Response Coefficient (AERC) in determining the earnings quality response coefficient value. Also, the study seeks to explain the effect of company characteristics and corporate governance on AERC through voluntary disclosure and information asymmetry. Research samples include 69 manufacturing companies listed on the Indonesian Stock Exchange over the period 2014-2017. The data come from annual reports, stock market prices, CSPI, EPS, stock returns and market returns. The research model is tested using the structural equation model (SEM) with partial least square (PLS). The results showed the value of the earnings response coefficient produced by AERC and ERC was different. Earnings quality resulting from AERC regression by adding CFO values better reflects the actual earnings quality. These results are consistent with the concept built from the proposition about earnings quality at AERC, that quality earnings are informative accounting earnings. The theoretical findings of this study provide an explanation that operational cash flow plays a role in evaluating earnings quality, while providing reinforcement that the ERC regression model fails to detect stock market reactions to information relevant to the aggregated values of accounting earnings.
\end{abstract}

Keywords: AERC, Corporate Governance, Voluntary Disclosure, Information Asymmetry, ERC

JEL Classification Code: G34, O43, G24, G32

\section{Introduction}

Earnings Response Coefficient (ERC) is an assessment of investors that starts in a situation around the date of the company's earnings announcement, where investors give different responses to reported earnings. If the reported profit of the company is higher than the investor's

${ }^{1}$ First Author and Corresponding Author. Associate Professor, Doctoral Program in Management Science, Universitas Jember, Indonesia [Postal Address: Street Gatot Subroto No.4, Veteran, Karangsari, Sukodono, Kabupaten Lumajang, Jawa Timur 67352, Indonesia] Email: pradnyataj@gmail.com

${ }^{2}$ Professor, Doctoral Program in Management Science, Universitas Jember, Indonesia. Email: istitatuk@yahoo.co.id

${ }^{3}$ Associate Professor, Doctoral Program in Management Science, Universitas Jember, Indonesia. Email: diana.tobing@unej.ac.id

${ }^{4}$ Associate Professor, Doctoral Program in Management Science, Universitas Jember, Indonesia. Email: imamsuroso.unej@gmail.com

(c) Copyright: The Author(s)

This is an Open Access article distributed under the terms of the Creative Commons Attribution Non-Commercial License (https://creativecommons.org/licenses/by-nc/4.0/) which permits unrestricted non-commercial use, distribution, and reproduction in any medium, provided the original work is properly cited. prediction, the investor revises upward the company's profit and performance evaluation and purchases shares, and vice versa, if the reported profit is lower than the prediction, the investor revises down and sells the company's shares.

Research on ERC is mostly conducted on influencing factors such as: company characteristics, corporate governance and the level of completeness of financial statement disclosures with mixed results. Dhaliwal et al. (1991) and Murwaningsari (2008) prove that leverage has a negative effect on earnings response coefficient. They also states that the amount of debt shows the quality of the company as well as the prospects that are not good in the future (Harris \& Raviv, 1990). For companies with high debt, an increase in profits further strengthens the position and security of bondholders compared to shareholders. While leverage shows a positive effect on ERC, companies that use a lot of funds from creditors show that the company is in good condition because it has the trust, so, the use of loans will not reduce the welfare of shareholders because the addition of debt does not mean there is an increase in the number of shares in circulation. (Martani, Mulyono \& Khairurizka, 2009). Hasanzade et al. (2013) concluded that 
leverage has no effect on ERC. Patatoukas (2014) discusses earnings quality with the dimensions of cash flows and the discount rate, and reaches the conclusion that cash flow plays an important role in influencing the quality of reported earnings, and the traditional ERC regression model fails to detect stock market reactions. Ball, Kothari, and Nikolaev (2013) help link the conservatism theory with the use of accounting information to measure ERC, and Al-Baidhani et al. (2017) recommend using accounting information from three main financial statements to assess ERC.

Company size is one of the determinants of ERC. Cho and Jung (1991) support a positive relationship for size effect on ERC. However, Chaney and Jeter (1992) and Murwaningsari (2008) revealed that there was a negative effect, this was because of the long window used in research where information about large companies was available throughout the year, causing a market reaction that was not so large around the announcement date profit (Murwaningsari, 2008). Collins and Kothari (1986) conducted research on firm size on ERC and obtained evidence that firm size did not provide additional explanatory power for differences in earnings response coefficients (Collins \& Kothari, 1989; Martani, Mulyono, \& Khairurizka, 2009; Okolie 2014; Collins \& Kothari, 1986).

Growth is a variable that explains the prospects for future growth. Companies that continue to grow more easily attract capital and this is a source of growth. Investors respond more easily to earnings information at these companies. According to Collins and Kothari (1986), growth and ERC have a positive influence. Growing companies have a higher ERC because the company has the opportunity to earn higher profits in the future. Hasanzade et al. (2013) and Okolie (2014) concluded that growth has a positive effect on ERC, the earnings information content is good news so that it can increase market response. Conversely, according to the liquidity risk hypothesis (Diamond, 1991, 1993; Sharpe, 1991; Vijayakumaran \& Vijayakumaran, 2019b), firms with high growth opportunities are expected to suffer from liquidity risk problems when they choose too much shortterm debt in order to reduce the underinvestment problems.

Palupi (2013) concludes that growth is negatively related to ERC, but not significant, because investors are investing not for the purpose of a long-term perspective to get the yield from investments made, but to get capital gains. The effect of profitability on earnings response has been shown to have a positive effect (Ball et al., 2008; Murwaningsari, 2008; Ball et al., 2016). Earnings response in companies that have high profitability is found to be greater than companies with low profitability. The reason is that the company that makes a profit is allegedly able to complete the operational activities that are being carried out. Hasanzade et al. (2013) also explained the results of their research in Iran that profitability had a positive effect on ERC. Meanwhile, for some studies (Moradi, Salehi, \& Erfanian, 2010; Kasznik 1999; Clarke et al., 2000), the efficient capital market theory says that the market should react more strongly to good news about operating cash flow than good news about accruals. This is believed because operating cash flow is more likely to recur over future periods compared to accruals. But in reality the market reacts more strongly to accruals than to operating cash flow.

Research (Wallace et al., 1994; Salamon \& Dhaliwal, 1980; Yuen, 2009; Izyani \& Wan 2010) related to firm size on voluntary disclosure showed positive results. According to Lorek and Willinger (2006), large companies are entities that are widely highlighted by the market and the public in general; disclosing more information is part of the company's efforts to realize public accountability. The effect of profitability on voluntary disclosure has been proven (Singhvi \& Desai, 1971; Izyani \& Wan, 2010), revealing that companies with high profitability will provide more voluntary disclosures to investors.

Corporate governance provides effective protection for shareholders and creditors so that investors believe they can get a return on their investment. Some corporate governance mechanisms are internal mechanisms, such as ownership structure and the structure of the board of commissioners as well as external mechanisms such as market control, institutional ownership, funding with debt, and conducting audits by external auditors are expected to overcome the existing agency problems (Babic \& Janosevic, 2001). Chtourou et al. (2001) provide evidence that boards of commissioners, audit committees and independent committees are effective in increasing the quality and quantity of information disclosed by companies, thereby reducing information asymmetry. To find the effect of corporate governance on the quality of profits, Qinghua, Pingxin, and Junming (2007) studied the relationship between audit committee, Board characteristics and EQ, as well as empirical research on the Chinese stock market. The authors measured the listed companies' EQ through the level of earning management (EM) using the adjusted Jones model. Corporate governance and earning quality studies have been conducted by many authors across the world (Dang et al., 2020) in two main directions: (1) studying the individual characteristics of CG affecting EQ, and (2) studying synthetic factors representing $\mathrm{CG}$, which impacts on $\mathrm{EQ}$.

The synthesis process is carried out first to bring up new concepts and subsequently testing the model. The findings of this study compare the earnings response coefficient values by using Earnings Response Coefficient (ERC) and by the new concept of synthesis, namely, Accounting Earnings Response Coefficient (AERC), and then we compare model tests. This research was conducted on the Indonesian Stock Exchange; it is suspected that the market reaction to the information contained in the company's earnings announcement around the date of publication of the financial 
statements could be different if the research was conducted on a foreign stock exchange. This research was conducted to test the characteristics of the company and corporate governance on Accounting Earning Response Coefficient in companies indexed on Indonesia's Stock Exchange over the period 2014-2017.

\section{Literature Review}

\subsection{Synthesis of Accounting Earnings Response Coefficient (AERC)}

Earnings quality can be defined as the ability of earnings information to respond to the market, meaning that reported earnings have a response strength. The strong market reaction to earnings information is reflected in the high Earnings Response Coefficients (ERC), indicating the reported earnings (Scott, 2015). Earning Response Coefficient (ERC) is a reaction to earnings announced by a company that reflects the quality of earnings reported by the company so that it is one of the measures or proxies used to measure earnings quality (Collins \& Kothari, 1989).

Theoretically, the volume of shares is greatly influenced as soon as the company announces its financial statements. If what happens is good news, investors will buy the company's shares, as a result the stock price will increase, and if there is bad news investors will sell the company's shares so that the stock price will go down. The increase and decrease in stock prices is reflected on the cumulative abnormal return (CAR) of each company. The difference between the actual return and the return obtained by the index model approach is the abnormal return, which is a reflection of a certain event. Abnormal returns can be measured using the difference model between actual returns and market returns (Ali \& Zarowin, 1992).

Petatoukas (2014) discusses earnings quality with the dimensions of cash flow and discount rates and concludes that cash flow plays a significant role in influencing reported earnings quality. His research concludes that the traditional ERC regression model fails to detect stock market reactions to news that are relevant to the aggregated value of accounting earnings because they experience variable problems that are omitted. Future studies are expected to be able to describe changes in aggregate earnings to identify which components are more correlated with new information that is relevant to the value of shares (income or expenses, accruals or cash flow).

$\mathrm{CAR}_{\mathrm{t}}$ represents the cumulative abnormal return of the company during the observation period $t$ from the date of publication of the financial statements. In this study, abnormal returns are calculated using the market-adjusted model, which explains that the estimated best return on market securities is at that time. To obtain abnormal return data, you must first look for daily stock returns and daily market returns. Unexpected Earnings (UX) is defined as the difference between the realized accounting profit and the accounting profit expected by the market. Unexpected Earning (UX) is calculated using EPS with a time series approach. Operational cash flow is the operating cash flow generated and used in the company's operational activities. The unstandardized value of unexpected earnings is the value of the AERC. The CFO value on the correlation between the abnormal return and unexpected earnings has the potential to provide real earnings quality information.

\subsection{Variable Corporate Governance}

Corporate governance is expected to function as a tool to provide investors with confidence that they will receive a return on the funds invested. Several mechanisms in corporate governance practices, such as independent commissioners, audit committees and audit quality are predicted to influence information asymmetry. Several empirical studies provide evidence that the mechanism of corporate governance is related to the use of debt capital in the capital structure. Friend and Lang (1988) and Vijayakumaran and Vijayakuraman (2019a) show that the level of leverage is negatively related to management's shareholding, implying that managers who have large stakes in the corporation use less corporate debt in order to reduce their non-diversifiable firm specific risk associated with their human capital vested in the firm. In addition, many empirical studies (e.g., Merhan, 1992; Berger; Brailsford, Oliver, \& Pua, 2002) show that other governance mechanisms such as the monitoring by outside block-holders and independent directors are positively associated with the increased use of debt-equity ratios in firms. A positive relation between external block holders and leverage suggests that large shareholders have greater incentives to monitor the management, resulting in decreased managerial opportunistic behavior and thus lower agency costs.

\section{Methodology}

This study was designed to explain the effect of company characteristics and corporate governance on AERC directly or indirectly through intervening voluntary disclosure and information asymmetry in manufacturing companies listed on the Indonesian Stock Exchange over the period 20142017. This study uses data from financial statements, annual reports, data on stock market prices and the composite stock price index (CSPI), earnings per share, daily stock returns, market returns of manufacturing companies listed on the Indonesia Stock Exchange. This research is a type of survey research that does not make changes or there is no special treatment of the variables studied. This research sample technique uses a purposive sampling method, while the research sample includes 69 companies listed on the Indonesia Stock Exchange. Data analysis method will be carried out 
using structural equation modeling (SEM) with Partial Least Square (PLS). The reason for using SEM PLS is because this study only uses a recursive path analysis model and the measurement scale of the variables in this study uses a ratio scale and a dummy scale (on one of the manifest variables).

\section{Results and Discussion}

\subsection{Testing the Results of Synthesis}

Accounting Earnings Response Coefficient (AERC) is the development of the concept of Earnings Response Coefficient (ERC) by adding operational cash flow (CFO) to the regression equation to measure the market response coefficient. Market response coefficient shows how much market response to company profits after the delivery of information on changes in earnings and cash flow. Patatoukas (2014) research states that at each company changes in earnings, cash flow and discount rates significantly influence market response. The concept presented by ERC is that the higher the ERC value, the more the quality of the company's profits, while the concept at AERC that quality earnings are actual profits that are reflected in the value of earnings after being corrected with the CFO. Following are the different test results for the ERC value and the AERC value presented in Table 1:

Different test results for the ERC and AERC values on the significant Paired Sample Test (0.000) mean that the value obtained by adding $\mathrm{CFO}$ to the $\mathrm{AERC}$ equation makes a difference to the ERC concept. These results indicate the quality of earnings generated from AERC regression by adding the value of CFO to the AERC equation is the quality of earnings after being corrected with CFO, so that the value of AERC better reflects the quality of actual earnings. This concept is built from the proposition about earnings quality at $\mathrm{AERC}$, that quality earnings are informative accounting earnings. The theoretical findings of this study provide support for the results of Patatoukas (2014) that operational cash flow plays a role in evaluating earnings quality, while providing reinforcement that the ERC regression model fails to detect stock market reactions to information relevant to the aggregated values of accounting earnings. The AERC concept affirms the Capital Assets Pricing Model (CAPM) which determines the relationship between returns and risk with the abnormal dimensions of returns. The concept was further developed Ball and Brown (1968) who examined the relationship between earnings and stock prices with earnings per share.

Collin and Kothari (1989) combine two concepts that measure earnings quality using the income response coefficient. While discussing earnings quality with the dimensions of cash flow and discount rates, Patatoukas (2014) concludes that cash flow plays an important role in influencing the quality of reported earnings. According to Hecht and Vuolteenaho (2005), cash flow statements can provide sufficient information for investors to make investments. The amount of cash flow from operating activities is an indicator that determines whether the company's operational activities can generate sufficient cash flow to pay off loans, maintain operational capability, pay dividends, and make new investments without relying on external funding sources. Cash flow statement information will be said to have meaning if it is used as a basis for decision making by investors. Paramita (2012) concluded that the positive influence of company size variables on earnings response coefficient (ERC) and voluntary disclosure, company size through voluntary disclosure affects the earnings response coefficient (ERC), while earnings persistence as a control variable has no effect on earnings response coefficient (ERC).

Table 1: Difference between ERC and AERC Values

\begin{tabular}{|c|c|c|c|c|c|c|}
\hline & \multicolumn{3}{|c|}{ AERC } & \multicolumn{3}{|c|}{ ERC } \\
\hline & VD & $\mathrm{Al}$ & AERC & VD & $\mathrm{Al}$ & ERC \\
\hline KP & $\begin{array}{r}0,343 \\
4,989 * *\end{array}$ & & $\begin{array}{c}0,174 \\
3,330^{* *}\end{array}$ & $\begin{array}{c}0,373 \\
5,847^{* * *}\end{array}$ & & $\begin{array}{c}0,036 \\
0,526^{\text {ts }}\end{array}$ \\
\hline CG & & $\begin{array}{l}-0,117 \\
2,459^{*}\end{array}$ & $\begin{array}{l}-0,328 \\
2,506^{* *}\end{array}$ & & $\begin{array}{l}-0,142 \\
2,285^{*}\end{array}$ & $\begin{array}{c}0,057 \\
0,890^{\text {ts }}\end{array}$ \\
\hline VD & & & $\begin{array}{c}0,060 \\
0,799^{\text {ts }}\end{array}$ & & & $\begin{array}{l}0,165 \\
2,517^{*}\end{array}$ \\
\hline $\mathrm{Al}$ & & & $\begin{array}{l}-0,009 \\
0,259^{\text {ts }}\end{array}$ & & & $\begin{array}{l}0,140 \\
2,430^{*} \\
\end{array}$ \\
\hline Value $\mathrm{R}^{2}$ & $\begin{array}{c}0,118 \\
2,854^{* *}\end{array}$ & $\begin{array}{c}0,014 \\
1,152^{\text {ts }}\end{array}$ & $\begin{array}{l}0,155 \\
1,840^{*}\end{array}$ & $\begin{array}{c}0,139 \\
3,460\end{array}$ & $\begin{array}{c}0,020 \\
1,374^{\text {ts }}\end{array}$ & $\begin{array}{l}0,054 \\
2,011^{*}\end{array}$ \\
\hline Paired Sample Test & & & & & & \\
\hline
\end{tabular}


In the model test results, parameter coefficient values and bootstrapping test results on models using AERC have better R Square values, this indicates that ERC and AERC variables have significant differences and AERC gives better values. The value of $\mathrm{R}$ Square in the ERC model is 0.054 , meaning that the contribution made by the variable under study to the ERC is $5 \%$. While the R Square value in the AERC model is 0.155 , meaning that the contribution made by the variables studied to the AERC is $15 \%$.

\subsection{AERC Model Test Results}

Bootstrapping test results of the significance of the path coefficient to explain the effect between variables on the inner research model are as follows (see Table 2):

Bootstrapping test results signify the path coefficient of the latent variable constructs to endogenous variables. A summary of the results of the hypothesis test is presented in Table 3.

This study also analyzes using moderation, which is to influence company characteristics on AERC through voluntary disclosure and the effect of corporate governance on AERC through information asymmetry. Statistical test value of $p=0.172$ for voluntary disclosure and value of $p=0.238$, states the results of the voluntary disclosure modification test is not significant to the asymmetry of AERC information. Testing results can be seen in table 4, below.

Hypothesis 1 is accepted, because the better characteristics of companies have a positive effect on the completeness of the voluntary disclosure by the company. Voluntary disclosure is disclosure of information that exceeds the mandatory disclosure required by the capital market supervisor. Companies have varying degrees of voluntary disclosure to provide more comprehensive information to investors as a result of research (Basu, 2005; Yuen, 2009). The company characteristics in this study are explained by leverage, growth, profitability and company size. Companies with good characteristics can be shown with a low level of leverage, good growth rates, good profitability and largescale company size.

Company leverage shows the proportion of the use of funds from creditors to finance its investment. Financial leverage must be treated as a risk calculation that is applied with the

Table 2: Bootstrapping Inner Model Test Results

\begin{tabular}{|l|c|c|c|c|c|c|}
\hline & \multicolumn{2}{|c|}{ VD } & \multicolumn{2}{c|}{ Al } & \multicolumn{2}{c|}{ AERC } \\
\hline & Parameter Coefficient & $\mathbf{t}$ statistic & Parameter Coefficient & t statistic & Parameter Coefficient & t statistic \\
\hline KP & 0,343 & $4,989^{* * *}$ & & & 0,174 & $3,330^{* *}$ \\
\hline CG & & & $-0,117$ & $2,459^{* *}$ & $-0,328$ & $2,506^{* *}$ \\
\hline VD & & & & & 0,060 & $0,799^{\text {ts }}$ \\
\hline Al & & & & & $-0,009$ & $0,259^{\text {ts }}$ \\
\hline Value R $\mathrm{R}^{2}$ & \multicolumn{2}{|c|}{0,118} & \multicolumn{2}{c|}{0,014} & \multicolumn{2}{c|}{0,155} \\
\hline
\end{tabular}

Table 3: Hypothesis Test Results

\begin{tabular}{|l|c|c|c|c|}
\hline Hypothesis & Influence between Variables & Parameter Coefficient & t statistic & Description \\
\hline Hypothesis 1 & $\mathrm{KP} \rightarrow \mathrm{VD}$ & 0,343 & $4,989^{* * *}$ & Significant \\
\hline Hypothesis 2 & $\mathrm{CG} \longrightarrow \mathrm{Al}$ & $-0,117$ & $2,459^{* *}$ & Significant \\
\hline Hypothesis 3 & $\mathrm{KP} \longrightarrow \mathrm{AERC}$ & 0,174 & $3,330^{* *}$ & Significant \\
\hline Hypothesis 4 & $\mathrm{CG} \rightarrow \mathrm{AERC}$ & $-0,328$ & $2,506^{* *}$ & Significant \\
\hline Hypothesis 5 & $\mathrm{VD} \rightarrow$ AERC & 0,060 & $0,799^{\text {ts }}$ & Not Significant \\
\hline Hypothesis 6 & $\mathrm{Al} \rightarrow \mathrm{AERC}$ & $-0,009$ & $0,259^{\text {ts }}$ & Not Significant \\
\hline
\end{tabular}

Table 4: Moderation Test Results

\begin{tabular}{|l|c|c|}
\hline & t statistic & Description \\
\hline $\mathrm{KP} \rightarrow \mathrm{VD} \rightarrow \mathrm{AERC}$ & $0,707^{\text {s }}$ & Not Significant \\
\hline $\mathrm{CG} \rightarrow \mathrm{Al} \rightarrow \mathrm{AERC}$ & $0,775^{\mathrm{ts}}$ & Not Significant \\
\hline
\end{tabular}


right conditions to produce maximum results. Leverage will be detrimental if the company cannot generate revenue from the use of these funds as much as a fixed burden to be paid. Barclay et al. (2003) mainly focus on the joint determination of leverage and maturity, as well as on the effect of growth opportunities on leverage and debt maturity. Johnson (2003) extends this work by empirically testing both predictions that short-maturity debt can mitigate the negative effect of high-growth opportunities on leverage (Myers, 1997; Hart \& Moore, 1995) on the one hand, and it increases liquidity risk on the other (Diamond, 1993; Sharpe, 1991). Using a large sample of 20,565 COMPUSTAT firm-year observations over the period 1986 to 1995, Johnson (2003) finds that, although leverage is negatively associated with growth opportunities, shortening debt maturity helps attenuate the negative effect of growth opportunities on leverage.

Companies with characteristics of low leverage will tend to make voluntary disclosures more fully in the hope of providing more comprehensive information to investors or potential investors. This study supports the research (Salamon \& Dhaliwal, 1980; Wallace et al., 1994; Na'im, 2000; Yuen, 2009; Izyani \& Wan, 2010; Nekhili et al., 2012; Banker, 2015; An, 2015; Karajeh, 2017). Characteristics of companies in the performance category are explained by profitability, namely, how the company's ability to generate profits. As one of the performance benchmarks for the company, profitability shows the company's ability to generate profits for a certain period at the level of sales, assets and share capital. In general, of course, the higher the return or income earned, the better the shareholder position. Companies with good profitability performance characteristics will tend to present more voluntary disclosures with the aim of conveying more information to investors and potential investors. The results of this study are in line with the results of other studies (Singhvi \& Desai, 1971; Izyani \& Wan, 2010).

Growth opportunities faced by the company in the future, show good prospects for bringing profits to the company by investing. The greater the opportunity for the company to grow, the higher the chance for the company to get profits in the future. Investors give a greater response to companies that have high growth; vice versa, investors will give a small response to companies with low growth possibilities. The faster growth rate indicates that the company is expanding. Failure caused by expansion will increase the company's burden because the company must cover the return of expansion expenses. This causes the distribution of dividends to shareholders to decline. These conditions can cause investors no longer interested in investing their capital in companies so they tend to sell their shares (Kallapur \& Trombley, 2001).
The first hypothesis of this study leads to the conclusion that the level of completeness of voluntary disclosure in annual reports is influenced by company characteristics. Companies with good characteristics tend to convey a lot of information to the market when company leverage is low, profitability is high, company growth rates are higher and company size is higher.

\subsection{The Effect of Corporate Governance on Information Asymmetry}

Hypothesis 2 is accepted, showing that good corporate governance will reduce information asymmetry. Corporate governance in this study was proxied by an audit committee, audit quality and an independent commissioner, asymmetry of information was proxied by the bid ask spread.

Corporate Governance has the primary goal of protecting the interests of shareholders and increasing the value of the company. Chtourou et al. (2001) provides evidence that audit committees and independent commissioners are effective in increasing the quality and quantity of information disclosed by companies, thereby reducing information asymmetry. The research examines audit committees and audit quality on bid ask, spreads and results from the existence of audit committees, and audit quality can reduce information asymmetry. This study provides the same results, corporate governance negatively affects information asymmetry. The existence of an independent commissioner's audit committee and the company's audit quality will help the company align the interests of shareholders with the manager. The information asymmetry in this study is reflected in the value of the spread, which is the magnitude of the information imbalance faced by the principal. The spread for a stock shows the difference in bid and ask prices determined by the principal when making transactions in the capital market. Bid ask is used as a measure of information asymmetry between management and company shareholders (Clarke et al., 2004).

The number of audit committees in each company is at least three people, this is in accordance with POJK number 55/POJK.04/2015 concerning the Establishment and Guidelines for the Implementation of Audit Committee Work. The results of this study indicate that $90 \%$ of companies have a minimum number of audit committees, the remaining $10 \%$ have an audit number exceeding the minimum requirements of four or five people. The results show the influence of the number of audit committees on improving corporate governance, so it is necessary for public companies to reconsider making additional numbers of corporate audit committees so that it is not only minimum. Furthermore, good corporate governance will reduce the gap between managers and shareholders. Whereas an independent Commissioner in 
accordance with POJK number 33/POJK.04/2014 concerning Directors and Board of Commissioners of Issuers or Public Companies is at least $30 \%$ of the total number of boards of commissioners. In this study, independent commissioners do not have a significant influence on corporate governance; on average, companies have $36 \%$ independent commissioners, indicating that the placement of independent commissioners in public companies is still at a minimum limit, where companies have $50 \%$ independent commissioners, with a ratio of two board of commissioners of which one of them is an independent commissioner. The use of external audit is a mechanism expected by the market with the aim of creating good corporate governance to reduce information asymmetry.

\subsection{Effect of Company Characteristics on Accounting Earnings Response Coefficient}

Hypothesis 3 is accepted, meaning that the characteristics of a good company, namely, low leverage, high growth rates, high profitability, and good company size will be responded well by the market. AERC data distribution values are very high indicating that the market response to earnings reported by the company varies greatly and investors respond to both information provided by the company such as leverage, growth, profitability, and size. Accounting Earnings Response Coefficient in this study is a proxy used to measure the quality of earnings contained in information that is responded by the market. Research on earnings quality has been carried out to test market reactions to corporate earnings announcements (Foster, 1977; Watts \& Zimmerman, 1983, 1996; Patell \& Wolfson, 1984; Siegal et al., 1996; Ball et al., 2000; Beaver, 2002; Lorek \& Willinger, 2006; Murwaningsari, 2008; Hasanzade et al., 2013).

This research is in line with (Dhaliwal, 1991; Murwaningsari, 2008; Haris et al., 2007) proving that leverage has a negative effect on earnings response coefficient. Cho and Jung (1991) support a positive relationship for effect sizes on ERC. Hasanzade et al. (2013) and Okolie (2014) concluded that growth has a positive effect on the income response coefficient, the income information content is good news so that it can improve market responses. According to Murwaningsari (2008) and Ball et al. (2015), earnings responses in companies that have high profitability are apparently greater than companies with low profitability. The effect of profitability on earnings response has been shown to have a positive effect. Meanwhile, Palupi (2013) shows a negative effect, that investors' investment goals are not for the long term but to get capital gains. Arfan (2008) concluded that there was no significant effect of high company profitability on the earnings coefficient. Collins and Kothari (1989) state that company size does not provide additional explanatory power for differences in earnings response coefficients.

\subsection{The Effect of Corporate Governance on Accounting Earnings Response Coefficient}

Hypothesis 4 can be accepted, meaning that investors will better respond to income information on companies that have good corporate governance. Good corporate governance is explained by companies that have high-quality financial statements and high-quality income information. Corporate governance rests on agency theory, which views that company management as an agent of shareholders will act with full awareness for its own interests, not as a wise and prudent and fair party for shareholders. One mechanism that can be used to overcome this problem is to implement a mechanism of good corporate governance. The mechanism of corporate governance has the ability in relation to producing financial statements that contain income information.

Corporate governance is definitively a system that regulates and controls companies that create added value for all stakeholders. This system is further built on the importance of the right of shareholders to obtain information correctly and on time, meaning that corporate governance is the company's obligation to make disclosures accurately, timely, transparently to all information on company performance, ownership, and stakeholders. So, good corporate governance is expected to increase the appreciation of shareholders or potential investors to the company's performance and can help align interests between management and shareholders. This concept gives investors the confidence that they will receive a return on the funds they invest (Myers, 2007). Internal corporate governance mechanisms such as audit committees and independent commissioner structures as well as external mechanisms such as conducting audits are expected to overcome agency problems (Nekhli et al., 2012). The placement of the audit committee, adit quality and independent commissioners as a proxy for corporate governance in this study has a significant influence on good corporate governance that was responded by Chtorou et al. (2001).

\subsection{The Influence of Voluntary Disclosure on Accounting Earnings Response Coefficient}

Hypothesis 5 is rejected, meaning that the completeness of voluntary disclosure of market response with accounting earnings response coefficient is not always good. Voluntary disclosure is information disclosure that exceeds the minimum disclosure requirements of applicable capital market regulations, and the company has the freedom to make voluntary disclosures in annual reports. Annual reports provide meaningful information for investors, because investor behavior in the market is basically influenced by the availability of more complete information. 
This study does not support the results of the research (Miller, 1999; Adhariani, 2005; Murwaningsari, 2008; Paramita, 2014) that investors have confidence in the expectations of returns, which are based on publicly-available information, however such beliefs are still influenced by how investors absorb information received and make revisions. Companies that present broader voluntary disclosures are companies that have good news, so that it will be responded positively by investors.

Positive responses by investors are not only based on earnings figures reported in financial statements by companies, but also various information presented in annual reports. Investors will use all available information to assess earnings quality, performance and predict. Voluntary disclosure in this study is constant, meaning that the company does not make changes to the disclosure items that are reported annually. This could be due to the fact that the FSA gives the breadth of the company to make disclosures according to the needs of the company and there are no provisions for adding content every year. The company presenting voluntary disclosures is also presented on the company's website which is an inseparable part of the company profile. This is of course the changes made by the company each year only limited to changes in data and not disclosure items. The availability of supplementary information throughout the year does not provide the strength of investor response on dates around the company's earnings announcements.

\subsection{Effect of Information Asymmetry on Accounting Earnings Response Coefficient}

The hypothesis six is rejected, meaning that the low information asymmetry does not always lead to the better market response with Accounting Earnings Response Coefficient. Investors in the efficient capital market hope that the information received can be used to compare profits between companies, so that differences in earnings quality can be known. Accounting earnings response coefficient is a measure of earnings quality that is indicated to provide response strength. In line with the efficient market theory investors will react immediately to new information on the market. Both companies that experience good news or bad news will have abnormal returns on average, which causes variations in earnings coefficients in the company (Ball \& Brown, 1968).

Asymmetry of information is divided into 1) adverse selection, namely, that managers and other insiders usually know more about the situation and prospects of the company than outsiders and there may be facts that are not conveyed to the principal and 2) moral hazard, namely, that the activities carried out by a manager are not entirely known by investors (shareholders, creditors), so that managers can take actions outside the knowledge of shareholders who violate contracts and in fact ethics or norms may not be appropriate. Bid ask spread as a component of adverse selection reflects the level of information asymmetry that occurs in the market. When investors make transactions under conditions of high information asymmetry, it is suspected that this will lead to greater bid ask spreads. But the high and low bid ask spead in the study did not cause the value of accounting earnings response coefficient also became high. This is due to the wide distribution of data on information asymmetry and also the high distribution of data on market responses, which indicates that the principle has a high information gap while the market does not respond to information provided by managers.

\section{Conclusion}

The results of this study indicate the quality of earnings generated from AERC regression by adding the value of CFO to the AERC equation is the quality of earnings after being corrected with CFO, so that the value of AERC better reflects the quality of actual earnings. The theoretical findings from this study provide an explanation that operational cash flow plays a role in evaluating earnings quality, while providing reinforcement that the ERC regression model fails to detect stock market reactions to information relevant to the aggregate value of accounting earnings. Companies with low leverage, high company growth, high profitability, and large scale companies will tend to make voluntary disclosures more complete in the hope of providing more comprehensive information to investors or potential investors.

Good corporate governance reduces the information asymmetry is proven in this study. Corporate governance was proxied by an audit committee, audit quality, and an independent commissioner. This study provides the results showing that corporate governance negatively affects information asymmetry, meaning that good corporate governance will reduce information asymmetry.

Good company characteristics, namely, low leverage, high growth rates, high profitability, and large-scale companies will be responded well by the market. Quality information available in the market can provide information and explanations that are quite influenced by good company characteristics. Investors will better respond to earnings information from companies that have good corporate governance. Good corporate governance is explained by companies that have quality financial statements and earnings information, and which has also high quality and good corporate governance that will have an impact on public trust. The better the completeness of voluntary disclosure, the better the market response with accounting earnings response coefficient. Voluntary disclosure is information disclosure that exceeds the minimum disclosure 
requirements of applicable capital market regulations and where the company has the freedom to make voluntary disclosures in annual reports. Annual reports do not provide meaningful information for investors, because companies in the presentation of disclosures do not make changes to the disclosure items so that information about voluntary disclosure can be obtained throughout the year by investors. The effect of information asymmetry on AERC was not demonstrated in this study. Low information asymmetry is not always responded well by the market. Investors in the efficient capital market hope that the information received can be used to compare profits between companies so that differences in earnings quality can be known. When investors make transactions under conditions of high information asymmetry, it is suspected that this will lead to greater bid ask spreads. But the high and low bid ask spread in the study did not cause the value of accounting earnings response coefficient also became high.

\section{References}

An, Y. (2015). Earnings Response Coefficients and Default Risk : Case of Korean Firms. International Journal of Financial Research, Sciedu Press, 6(2), 67-71.

Al-Baidhani, A., Abdullah, A., Ariff, M., Cheng, F. F., \& Karbhari, Y. (2017). Review of earnings response coefficient studies. Corporate Ownership and Control, 14(3), 299-308. https://doi. org/10.22495/cocv14i3c2art4

Adhariani, D. (2005). Extent of Voluntary Disclosure in Annual Reports and Its Relationship with Current Earnings Response Coefficient (ERC). Jurnal Akuntansi Dan Keuangan Indonesia, 2(1), 24-57. https://doi.org/10.21002/jaki.2005.02

Ali, A., \& Zarowin, P. (1992). Permanent versus transitory components of annual earnings and estimation error in earnings response coefficients. Journal of Accounting and Economics, 15(2-3), 249-264. https://doi.org/10.1016/01654101(92)90020-3

Barclay, M. J., Marx, L. M., \& Smith, C. (2003). The joint determination of leverage and maturity. Journal of Corporate Finance, 9(2), 149167. https://doi.org/10.1016/S0929-1199(02)00003-2

Babic, V., \& dan Janosevic, S. (2001). How to Improve the Process of Strategic Change Management in Transition Economy Enterprises. In: Strategic Management Society: 21st Annual International Conference, San Francisco, CA.

Ball, R., \& Brown, P. (1968). An empirical evaluation of accounting income numbers. Journal of Accounting Research, 6(2), 159178.

Ball, R., Kothari, S. P., \& Nikolaev, V. V. (2013). Econometrics of the Basu Asymmetric Timeliness Coefficient and Accounting Conservatism. Journal of Accounting Research, 51(5), 10711097. https://doi.org/10.1111/1475-679X.12026

Ball, R., Gerakos, J., Linnainmaa, J. T., \& Nikolaev, N. (2015). Accruals, Cash Flows, and Operating Profitability in the Cross
Section of Stock Returns. Journal of Financial Economics, 121(1), 28-45.

Ball, R., Robin, A., \& dan Sadka, G. (2008). Is Financial Reporting Shaped by Equity Markets or by Debt Markets? An International Study of Timeliness and Conservatism. Review of Accounting Studies, 13(2-3), 168-205. https://doi.org/10.1007/s11142-0079064-X

Ball, R., Gerakos, J., Linnainmaa, J. T., \& Nikolaev, V. (2016). Accruals, cash flows, and operating profitability in the cross section of stock returns. Journal of Financial Economics, 121(1), 28-45. https://doi.org/10.1016/j.jfineco.2016.03.002

Banker, R. D., Byzalov, D., \& Chen, L. T. (2013). Employment protection legislation, adjustment costs and cross-country differences in cost behavior.Journal of Accounting and Economics, 55(1), 111-127. https://doi.org/10.1016/j.jacceco.2012.08.003

Basu, S. (2005). Discussion of Conditional and Unconditional Conservatism : Concepts and Modeling. Review of Accounting Studies, 10(2), 311-321.

Berger, P. G., Ofek, E., \& Yermack, D. L. (1997). Managerial entrenchment and capital structure decisions. Journal of Finance, 52, 1411-1438. https://doi.org/10.1111/j.1540-6261.1997. tb01115.x

Beaver, W., Lambert, R., \& Morse, D. (1980). The information content of security prices. Journal of Accounting and Economics, 2(1), 3-28.

Brailsford, T. J., Oliver, B. R., \& Pua, S. L. (2002). On the relation between ownership structure and capital structure. Accounting and Finance, 42(1), 1-26. https://doi.org/10.1111/1467629X.00001

Chaney, P. K., \& Jeter, D. C. (1992). The effect of size on the magnitude of long-window earnings response coefficients. Contemporary Accounting Research, 8(2), 540-560. https://doi. org/10.1111/j.1911-3846.1992.tb00860.x

Clarke, J. E., Fee, C. E., \& Thomas, S. (2004). Corporate diversification and asymmetric information: Evidence from stock market trading characteristics. Journal of Corporate Finance, 10(1), 105-129. https://doi.org/10.1016/S09291199(02)00050-0

Cho, J. Y., \& Jung, K. (1991). Earnings response coefficients: A synthesis of theory and empirical evidence. Journal of Accounting Literature, 10(1), 85-116.

Collins, D. W., \& Kothari, S. P. (1986). An Analysis of Intertemporal and Cross-Sectional Determinants of Earnings Response Coefficients. Journal of Accounting and Economics, 11( 2-3), 143-181.

Collins, D. W., \& Kothari, S. P. (1989). An analysis of intertemporal and cross-sectional determinants of earnings response coefficients. Journal of Accounting and Economics, 11(2-3), 143-181.

Dhaliwal, D. S., Lee, K. J., \& Fargher, N. L. (1991). The association between unexpected earnings and abnormal security returns in the presence of financial leverage. Contemporary Accounting Research, 8(1), 20-41. https://doi. org/10.1111/j.1911-3846.1991.tb00832.x 
Dang, H. N., Pham, C. D., Nguyen, T. X., \& Nguyen, H. T. T. (2020). Effects of Corporate Governance and Earning Quality on Listed Vietnamese Firm Value. Journal of Asian Finance, Economics and Business, 7(4), 71-80. http://doi.org/10/13106/ jafeb.2019.vol7.no4.71

Diamond, D. W. (1991). Debt maturity structure and liquidity risk. The Quarterly Journal of Economics, 106, 709-737. https://doi. org/10.2307/2937924

Diamond, D. W. (1993). Seniority and maturity of debt contracts. Journal of Financial Economics, 33, 341-368. https://doi. org/10.1016/0304-405X(93)90011-Y

Foster, L. T., \& Jones, K. G. (1977). Applied Geography: An Educational Alternative. The Professional Geographer, 29(3), 300-304. https://doi.org/10.1111/j.0033-0124.1977.00300.x

Friend, I., \& Lang, L. (1988). An empirical test of the impact of managerial self-interest on corporate capital structure. Journal of Finance, 43, 271-281. https://doi. org/10.1111/j.1540-6261.1988.tb03938.x

Hart, O., \& Moore, J. (1995). Debt and seniority: An analysis of hard claims in constraining management. American Economic Review, 85, 567-585.

Harris, M., \& Raviv, A. (1990). Capital Structure and the Informational Role of Debt. The Journal of Finance, 45(2), 321-349.

Hasanzade, M., Darabi, R., \& Mahfoozi, G. (2013). Factors Affecting the Earnings Response Coefficient: An Empirical study for Iran. European Online Journal of Natural and Social Sciences: Proceedings, 2(3), 2551-2560.

Hecht, P., \& Vuolteenaho, T. (2006). Explaining Returns with CashFlow Proxies. Review of Financial Studies, 19(1), 159-194. https://doi.org/10.1093/rfs/hhj001

Izyani, W., \& Wan, A. (2010). Corporate Governance Mechanisms and Extent of Disclosure : Evidence from Listed Companies in Malaysia, International Business Research, 3(4), 216-228.

Johnson, S. (2003). Debt maturity and the effects of growth opportunities and liquidity risk on leverage. Review of Financial Studies, 16, 209-236. https://doi.org/10.1093/rfs/16.1.0209

Kallapur, S., \& Trombley, M. A. (2001). The investment opportunity set: determinants, consequences and measurement. Managerial Finance, 27(3), 3-15.

Karajeh, A. I., Ibrahim, M. Y. B., \& Lode, N. A. B. (2017). Impact of Shareholder Structure on Voluntary Disclosure in Malaysian Companies. Global Business and Management Research, 9(1), 142.

Kasznik, R., \& Lev, B. (1995). To warn or not to warn: Management disclosures in the face of an earnings surprise. Accounting Review: A Quarterly Journal of the American Accounting Association, 70(1), 113-134.

Lorek, K. S., \& Willinger, G. L. (2008). Time-series properties and predictive ability of quarterly cash flows. Advances in Accounting, 24(1), 65-71. https://doi.org/10.1016/j. adiac.2008.05.010
Martani, D., \& Khairurizka, R. (2009). The effect of financial ratios, firm size, and cash flow from operating activities in the interim report to the stock return. Chinese Business Review, 8(6), 44-55. https://doi.org/10.17265/1537-1506/2009.06.005

Miller, G. S. (1999). Earnings Performance and Discretionary Disclosure. Journal of Accounting Reasearch, 40(1), 173-204.

Moradi, M., Salehi, M., \& Erfanian, Z. (2010). A Study of the Effect of Financial Leverage on Earnings Response Coefficient through out Income Approach: Iranian Evidence. International Review of Accounting, Banking and Finance, 2(2), 76-84.

Murwaningsari, E. (2008). Simultaneous testing: several factors that affect the Earning Response Coefficient (ERC), National Symposium on Accounting, 11, 18-24.

Myers, S. (1977). Determinants of Corporate Borrowing. Journal of Financial Economics, 5, 147-175. https://doi. org/10.1016/0304-405X(77)90015-0

Na'im, A. (2000). Analysis of the Relationship Between Completeness of Financial Statement Disclosures with Capital Structure and Type of Ownership. Journal of Economic and Business Indonesia, 15(1), 18-28.

Nekhili, M., Boubaker, S., \& Lakhal, F. (2012). Ownership Structure, Voluntary R dan D Disclosure and Market Value of Firms: The French Case. International Journal of Business, 17(2), 126-140.

Okolie, A. (2014). Audit Quality and Earnings Response Coefficients of Quoted Companies in Nigeria. Journal of Applied Finance \& Banking, 4(2), 139-161.

Patatoukas, P. N. (2014). Detecting news in aggregate accounting earnings: implications for stock market valuation, Review Accounting Study, 19, 134-160. https://doi.org/10.1007/s11142013-9221-3

Patell, J. M., \& Wolfson, M. A. (1984). The intraday speed of adjustment of stock prices to earnings and dividend announcements. Journal of Financial Economics, 13(2), 223252. https://doi.org/10.1016/0304-405X(84)90024-2

Palupi, M. J. (2013). Factors Affecting the Profit Response Coefficient: Empirical evidence on manufacturing companies. The Indonesian Journal of Accounting Research. https://ijariaikapd.or.id/index.php/ijar/article/view/153

Paramita, R. W. D. (2012). Effect of Firm Size on Earnings Response Coefficient (ERC) with Voluntary Disclosure as an Intervening Variable (Study of Manufacturing Companies Listed on the Indonesia Stock Exchange). WIGA: Journal of Economic Research, 2(1), 64-79.

Paramita, R. W. D. (2014). Timeliness as an Intervening Variable for the effect of Size on ERC. WIGA: Journal of Economic Research, 4(1), 34-42.

Qinghua, W., Pingxin, W., \& Junming, Y. (2007). Audit committee, board characteristics and quality of financial reporting: An empirical research on Chinese securities market. Frontiers of Business Research in China, 1(3), 385-400.

Salamon, G. L., \& Dhaliwal, D. S. (1980). Company size and financial disclosure requirements with evidence from the 
segmental reporting issue. Journal of Business Finance and Accounting, 7(4), 555-568.

Sharpe, S. A. (1991). Credit rationing, concessionary lending, and debt maturity. Journal of Banking \& Finance, 15(3), 581-604. https://doi.org/10.1016/0378-4266(91) 90087-3

Siegal, W., Church, A. H., Javitch, M., Waclawski, J., Burd, S., Bazigos, M., Yang, T.-F., Anderson-Rudolph, K., \& Warner Burke, W. (1996). Understanding the management of change: An overview of managers' perspectives and assumptions in the 1990s. Journal of Organizational Change Management, 9(6), 54-80.

Singhvi, S. S., \& Desai, H. B. (1971). An empirical analysis of the quality of corporate financial disclosure. The Accounting Review, 46(1), 129-138.

Vijayakumaran, S., \& Vijaykumaran, R. (2019a). Corporate Governance and Capital Structure Decisions: Evidence from Chinese Listed Companies. Journal of Asian Finance, Economics and Business, 6(3), 67-79. http://doi.org/10/13106/ jafeb.2019.vol6.no3.67
Vijayakumaran, S., \& Vijaykumaran, R (2019b). Debt Maturity of Growth Opportunities and Liquidity Risk on Leverage: Evidence from Chinese Listed Companies. Journal of Asian Finance, Economics and Business, 6(3), 27-44. http://doi. org/10/13106/jafeb.2019.vol6.no3.27

Wallace, R. S. O., Naser, K., \& Mora, A. (1994). The relationship between the comprehensiveness of corporate annual reports and firm characteristics in Spain. Accounting and Business Research, 25(97), 41-53.

Watts, R. L., \& Zimmerman, J. L. (1983). Agency problems, auditing, and the theory of the firm: Some evidence. The Journal of Law and Economics, 26(3), 613-633.

Watts, R. L., \& Zimmerman, J. L. (1996). Positive accounting theory: a ten year perspective. Accounting Review, 65(1), 131-156.

Yuen, D. C. Y. (2009). A Case Study of Voluntary Disclosure by Chinese Enterprises, Asian Journal of Finance and Accounting, 1(2) 118-145. 